Amelia Macioszek

Freie Universität Berlin

\title{
Safawidzkie adaptacje chińskich talerzy typu kraak
}

W wytworach ludzkiej wyobraźni adaptacja jest norma, a nie wyjątkiem. (Linda Hutcheon)

Chińska porcelana typu kraak i jej ogólna charakterystyka

Porcelanę typu kraak produkowano w Chinach w okresie panowania cesarza Wanli (1572-1620) do około 1640 roku. Był to jeden z pierwszych rodzajów porcelany importowanych do Europy w masowych ilościach. Jeśli chodzi o nazwę kraak, to pochodzi ona od portugalskich statków (carrak/caracca), w których transportowano porcelanę lub od holenderskiego słowa kraken 'tłuc się/bić'. Termin ten również odnosi się do rodzaju szafek, w których eksponowano importowaną porcelanę w Holandii.

Odróżnienie porcelany typu kraak od innych rodzajów wyrobów błękitno-białych nastręczać może wiele trudności, ale uczeni zgodni są, że do tego rodzaju należą naczynia, których dekoracje podzielone zostały na rezerwy. Problematyczne są wyroby, które nie mają owego podziału i w związku z tym przez część uczonych nie są uważane za 
kraaki. Obok talerzy występują też inne kształty naczyń, takie jak klapmutsen ${ }^{1}$, miseczki i tak zwane formy zamknięte, do których zalicza się wszelkie wazony i flasze.

Maura Rinaldi (Rinaldi 1989) dzieli chińskie talerze porcelanowe typu kraak na 9 podkategorii ${ }^{2}$ w zależności od rodzaju dekoracji, która występuje na otoku naczyń (rys. 1). Grupy I-III charakteryzują się brakiem podziału dekoracji na rezerwy. Bardzo charakterystyczna jest grupa I, w której talerze nie mają dekorowanych otoków, a tylko lustra. W następnej, II grupie pojawiają się dekoracje na otoku, jednak są one oszczędne i często wyodrębniony jest osobny pas pozbawiony dekoracji $\mathrm{w}$ przestrzeni między otokiem a lustrem talerza. III grupa zawiera niejako zalążek podziału na rezerwy z lekkim rowkowanym wcięciem dekoracji otoku oraz umieszczonymi po drugiej stronie wcięć, na obrębie talerza, głowami berła ruyi.

Grupy IV-VI mają już widocznie zarysowane rezerwy. W grupie IV podział następuje przez zaznaczenie widocznych prostych linii dzielących otok na rezerwy. Rezerwy w grupie V wyodrębnione są również poprzez rysunek prostych linii, jednakowoż w odróżnieniu od poprzedniej grupy pomiędzy poszczególnymi szerszymi rezerwami umieszczono rezerwy węższe, z innym rodzajem dekoracji, zazwyczaj przedstawiającej sznur korali lub rząd kropek je imitujących. W grupie VI między naprzemiennie umieszczone węższe i szersze rezerwy wkrada się więcej przestrzeni, która często zaznaczona jest jasnym odcieniem błękitu. Węższe rezerwy zaczynają też mieć wyraźnie wyodrębnioną część górną, zazwyczaj dekorowaną malowaniem jasnym odcieniem błękitu bądź motywami siatki lub rybiej łuski. Te same dekoracje pojawiają się $\mathrm{w}$ górnych i dolnych częściach wąskich rezerw w grupie VII. Dodatkowo sznur korali bywa zastępowany ozdobnymi kokardami. Tak jak w przypadku poprzedniej grupy, przestrzeń między rezerwami malowana jest odcieniem błękitu kobaltowego, który często przybiera ciemniejszy odcień niż w grupie VI.

Nowym elementem typowym dla grupy VII jest charakterystyczny pas usytuowany między otokiem a lustrem talerza. Złożony jest on

1 Jest to forma pośrednia między miseczką a głębokim talerzem, wyrabiana specjalnie na potrzeby europejskie i dostosowana do kształtu tutejszych łyżek, które w przeciwieństwie do chińskich mają wypukłe spody, by mogły swobodnie opierać się o ścianki. Przykład naczynia o kształcie klapmutsen znajduje się pod linkiem: http://www.cathy-hunt.co.uk/oriental-antiques/d/ming-kraak-blue-and-white-

klapmutsen-bowl/132907/, dostęp: 21.10.2014. Proszę zwrócić uwagę na ujęcie z boku ukazujące charakterystycznie wyprofilowany otok i ścianki.

2 Z uwagi na to, że występują też formy pośrednie i naczynia wskazujące na odstępstwa od reguł, należy zaznaczyć, iż przedstawiony dalej opis ma charakter ogólny. 
z takiej samej ilości części, jak i rezerw, a motywy często występują naprzemiennie (np. motyw łuski - motyw siatki - motyw łuski). Pod każdą węższą rezerwą znajduje się głowa berła ruyi, co nadaje pasowi wyrazu charakterystycznych upięć. M. Rinaldi w grupie VII wyróżnia trzy podgrupy oraz zwraca uwagę, że dekorowano też spodnie części naczyń (Rinaldi 1989: 97). Dekoracje otoku talerzy z grupy VIII zbliżone są do tych z grupy III. Ponadto występuje tu stosunkowo szeroki okrąg złożony $\mathrm{z}$ charakterystycznych łukowatych wcięć, zazwyczaj pomalowany ciemnym odcieniem błękitu kobaltowego. Tak jak w przypadku grupy III, wcięcia dzielą otok na pseudorezerwy, jednak tym razem są one jajowate i bardziej przypominają medaliony.

W dekoracji otoku talerzy z grupy IX uwagę zwraca podobieństwo do grupy IV, polegające na braku węższych rezerw. Jednakże szerokie rezerwy nie stykają się ze sobą, a przestrzeń między nimi wypełniona jest jasnym odcieniem błękitu. Znany z grupy VII wewnętrzny okrąg dekoracyjny z charakterystycznymi podpięciami zostaje zastąpiony równym, wypełnionym motywami roślinnymi i zwierzęcymi.

Motywy dekoracyjne zdobiące talerze typu kraak to zazwyczaj rośliny i zwierzęta. Przeważają znane z malarstwa chińskiego kompozycje złożone z kwiatów i ptaków, kwiatów i owadów, owoce brzoskwini czy granatu, ale pojawiają się również scenki rodzajowe (zwłaszcza w przypadku otoku grupy IX czy samych luster talerzy), zwoje i symbole. Bardzo ciekawym motywem często występującym na lustrach talerzy i równie chętnie adaptowanym przez perskich twórców, o czym jeszcze będzie mowa, jest wazon z kwiatami. Zazwyczaj ustawiony na stoliku bądź podstawce z korzeni i wypełniony po brzegi kwiatami chryzantemy oraz ozdobnymi zwojami wywoływać musiał konsternację wśród Persów, dla których stał się jednym z ulubionych wzorów do adaptacji.

\section{Perskie adaptacje talerzy typu kraak - ogólna charakterystyka}

Interakcja między Chinami i Persją dokonywała się poprzez Szlak Jedwabny i handel morski. W czasach panowania dynastii Tang wymiana handlowa została zintensyfikowana. Doprowadziło to do tego, że Chińczycy chętnie zapożyczali perskie kształty naczyń, dzięki temu nastąpiły także pierwsze eksporty kobaltu do Chin. Wiek XIII i XIV to czasy panowania Mongołów i kontrolowania przez nich wielu szlaków, co przyczyniło się do zwiększenia eksportu kobaltu do Chin i importu chińskiej porcelany. 
Należy wspomnieć, że użycie kobaltu do dekoracji naczyń na Bliskim Wschodzie rozpoczęło się znacznie wcześniej niż w Chinach. Pierwsze naczynia dekorowane tym minerałem powstawały już w IX wieku w Samarze. Podział otoku talerzy bądź ścianek innych naczyń na rezerwy $\mathrm{w}$ świecie islamu również nie był niczym nowym, albowiem pojawił się już w czasach średniowiecznych.

Czasy panowania Abbasa I (1587-1629) to okres reform i promowania rozwoju sztuk użytkowych, zwłaszcza garncarstwa, kobiernictwa, jedwabnictwa i metaloplastyki. Ten współczesny chińskiemu cesarzowi Wanli władca chętnie nawiązywał kontakty handlowe z Europą, z czego skorzystali Portugalczycy i Holendrzy, a sama wymiana handlowa przyniosła również Persji znaczne dochody. Legenda głosi, że Abbas I zaprosił kilkuset chińskich garncarzy, by się osiedlili w Persji, nie ma jednak żadnych dowodów na potwierdzenie tej informacji (Rinaldi 1989: 213).

Porcelana kraak była importowana przez Gamron (współczesny Bandar-e Abbas) od 1623 roku. Jeśli chodzi o talerze porcelanowe tego typu, to zazwyczaj adaptowano typy I-III, IV i VII oraz dzielono je na 6 bądź 8 rezerw. Dekoracje zwracają uwagę podobieństwem do chińskich oryginałów i dbałością o szczegóły. Natomiast ich zarysy często były wykonywane czernią lub bardzo ciemnym odcieniem błękitu kobaltowego ${ }^{3}$. Najbardziej zbliżone do chińskich oryginałów były adaptacje wykonywane w Kermanie i Meszhedzie. T. Volker w publikacji poświęconej ewidencji VOC zauważa, że w Persji preferowano chińską porcelanę ze znakami nianhao na odwrocie naczyń (Volker 1971: 88), a więc je również adaptowano w mniej lub bardziej udany sposób ${ }^{4}$. Już pobieżna obserwacja adaptacji wskazuje, że Perscy garncarze lubili mieszać style i dodawać własne elementy do adaptowanych motywów dekoracyjnych. Podobnie jak w przypadku chińskich wyrobów typu kraak o innych kształtach niż talerze, podział na rezerwy stosowany był również na naczyniach o formie zamkniętej, takich jak: kendi, flasze, miseczki czy dzbany. Co ciekawe, porcelana kraak była również źródłem inspiracji dla tak zwanych wy-

3 Według Rinaldi stosowanie czerni to wybieg umożliwiający zatrzymanie spływania kobaltu rozpuszczonego przez szkliwo (Rinaldi 1989: 215). Jednakże autorka jest innego zdania i sądzi, że służyło to po prostu celom dekoracyjnym, zważywszy na długą tradycję używania kobaltu obok czerni na ceramice w wiekach wcześniejszych (nie tylko w Persji, lecz również w Syrii czy Egipcie).

4 Por.: ciekawy artykuł na temat perskich adaptacji chińskich inskrypcji umieszczanych na spodach naczyń (Golombek 2001). 
robów Kubachi, wytwarzanych co prawda w okolicach Isfahanu ${ }^{5}$, lecz odnalezionych właśnie w rejonie miejscowości Kubachi znajdującej się na Kaukazie. Naczynia Kubachi, będące adaptacjami porcelan błękitno-białych, charakteryzują się dużą swobodą w traktowaniu chińskich źródeł.

Perskie adaptacje porcelany kraak były kupowane i wysyłane przez Holendrów z Gamronu do Batavii, by tam mogły być dystrybuowane po Południowej Azji zamiast chińskich oryginałów w czasie wojen i zamieszek panujących w Chinach pod koniec dynastii Ming (1657-1681). Było to około 1600 sztuk rocznie, co jest dość małą liczbą $\mathrm{w}$ porównaniu do kilkuset tysięcy eksportowanych $\mathrm{z}$ Chin (Volker 1971: 116).

\section{Dlaczego adaptacja?}

Badacze muszą powoli przekraczać ściśle określone ramy swoich dziedzin, by móc trafniej określać i opisywać zjawiska, którymi się zajmują. To samo dotyczy historii sztuki, która ostatnio staje się bardziej otwarta na takie pola badań jak socjologia, etnografia, szeroko pojęte kulturoznawstwo czy behawioryzm. Wkraczanie na tereny innych nauk niesie za sobą konieczność zmiany bądź zastosowania nowego słownictwa w celu trafniejszego określenia badanych zjawisk. Do określeń, których używa się w celu nazwania form odtwórczych, należą następujące terminy: kopia, replika, falsyfikat, stylizacja, imitacja, naśladownictwo, wariacja, zapożyczenie, cytat, transformacja, tłumaczenie i adaptacja. W szerokim rozumieniu różnica między tymi pojęciami polega na relacji między źródłem a formą naśladowczą bądź intencją autora dzieła. Kopia i replika stanowią bardzo bliskie odwzorowanie źródła, a ich celem zazwyczaj jest bycie tańszą i przez to bardziej dostępną wersją oryginału. Słowem „falsyfikat” określa się wyroby, których celem jest oszukanie widza. Stylizacja odnosi się do sytuacji, w których dzieło odtwórcze tylko przypomina źródło bądź charakterystyczne cechy prac określonego artysty czy stylu (Ja-

5 Jeszcze do niedawna za miejsce powstania tego ciekawego rodzaju ceramiki uważano północno-zachodni Iran. Ostatnie badania przeprowadzone przez R. B. Masona dowodzą, że ten specyficzny rodzaj ceramiki produkowany był w okolicach Isfahanu, a dokładniej w miejscowości Qumisheh położonej $84 \mathrm{~km}$ na południe od safawidzkiej stolicy. To, w jaki sposób dość spore ilości tej ceramiki znalazły się tak daleko, nadal pozostaje niewyjaśnione. Nie wyklucza się, że mieszkańcy Kubachi kolekcjonowali ceramikę. Możliwe jest również, że ceramika ta została tam przeniesiona w XIX wieku (Golombek 2014: 169-182). 
coby 2009: 19-20). Imitacja to termin znany już od antyku i dobrze zbadany. Jest to najpopularniejsze słowo, obok często równoważnego w języku polskim „naśladownictwa”, określające formy odtwórcze, zwłaszcza w sytuacjach, gdy należy szybko nazwać dany przedmiot bez zagłębiania się w teoretyczne szczegóły. Sprawia to, że oba terminy są powszechnie używane nie tylko w języku polskim, ale również w języku angielskim (imitation) i niemieckim (Nachahmung), zarówno potocznie, jak i przez specjalistów takich jak kuratorzy kolekcji azjatyckich w Muzeum Metropolitan w Nowym Jorku ${ }^{6}$.

Kategoriami, które ostatnio zdobywają popularność wśród historyków sztuki, są tłumaczenie i transformacja. Obydwie na pierwszy rzut oka wydają się trafnie określać zjawiska powtórzeń, jednakowoż nie oddają złożoności procesów towarzyszących twórcom podczas wyrabiania form odtwórczych. „Tłumaczenie” jest słowem bardzo kuszącym, gdyż oznacza miedzy innymi wyjaśnienie, interpretację czegoś, a także opracowanie tekstu w innym języku niż oryginał ${ }^{7}$. Tłumacz, dokonując przekładu, wyjaśnia to, co nie było znane, a więc też filtruje dane dzieło literackie i w pewien sposób adaptuje je do danej kultury. Nieznane idiomy przekłada na ich rodzime odpowiedniki i sprawia, że dany tekst może dotrzeć do szerszej publiczności. Jednakowoż celem, który przyświeca tłumaczowi, nie jest swobodna wypowiedź na temat danego dzieła, a tylko jak najwierniejsze przedstawienie tego, co napisał autor oryginału. To samo odnosi się do odbiorców - czytelników. Sięgając po polskie tłumaczenia dzieł Szekspira, chcą oni poznawać jego dzieła, a nie frywolne notatki z ostatnich wakacji tłumacza przeplatane cytatami z wielkiego mistrza. Tłumacz nie czyni z dzieła, które przekłada, części swojej własnej twórczości. Mimo że jego nazwisko widnieje na jednej z pierwszych stron książki, nie jest on autorem nowej kompilacji złożonej z kilku dzieł twórcy, a tylko tłumaczem określonego oryginału. Tłumacz staje się pośrednikiem między oryginałem a odbiorcami i dzięki jego staraniom możemy czytać wspaniałe dzieła literatury, które inaczej nie byłyby dla nas dostępne. Dlatego też tłumaczenie nie jest trafnym określeniem dla zjawisk, które zachodzą podczas powstawania form odtwórczych nie tylko w safawidzkiej Persji.

6 Por.: http://www.metmuseum.org/collection/the-collectiononline $/$ search $/ 451907 ?=\& i m g N o=0 \&$ tabName $=$ gallery-label, dostęp: 04.07.2014 lub http://www.metmuseum.org/collection/the-collectiononline $/$ search $/ 449547 ?=$ \&imgNo = 0\&tabName = gallery-label, dostęp: 04.07.2014

7 Słownik języka polskiego, http://sjp.pwn.pl/szukaj/t\%C5\%82umaczenie.html, dostęp: 23.10.2014. 
Kolejny kuszący termin, ostatnio bardzo popularny wśród historyków sztuki, transformacja, oznacza przemianę, przeobrażenie, przekształcenie i przeistoczenie ${ }^{8}$. Zatem transformacja znajduje zastosowanie tylko w przypadkach, gdy opisuje głębokie zmiany struktury, wyglądu czy charakteru przedmiotów bądź zjawisk. Dlatego słowo to nie jest odpowiednie w sytuacjach, gdy podobieństwo między źródłem a formą naśladowczą jest bardzo bliskie.

Adaptacja to ogólnie „przystosowanie do panujących lub zmieniających się warunków" (Allen 1992: 10), a bardziej szczegółowo:

1. przystosowanie czegoś do innego użytku niż było przeznaczone

2. przystosowanie utworu literackiego do wystawienia na scenie lub do sfilmowania; też: utwór literacki w ten sposób przystosowany

3. przystosowanie organizmów do warunków środowiska

4. zmniejszenie odczuwania określonych bodźców ${ }^{9}$.

Właśnie znaczenie pierwsze, „przystosowanie czegoś”, a także trzecie, „przystosowanie organizmów do warunków środowiska”, są głównymi powodami, dla których autorka zdecydowała się użyć słowa „adaptacja” dla określenia zarówno form naśladowczych chińskich porcelan typu kraak wyrabianych w safawidzkiej Persji, jak i samego procesu wytwarzania, a więc przystosowywania owych form. Ów dualizm pozwalający na nazwanie przedmiotów i zjawiska (adaptacja jako produkt i jako proces) sprawia, że jest to pojęcie bardzo skomplikowane i wymagające doprecyzowania.

Pośród najważniejszych kwestii, które są poruszane przez autorkę w prezentowanych badaniach, są zagadnienia takie jak: relacja między źródłem a adaptacją, wrogość w stosunku do adaptacji, intertekstualność (a raczej interobrazowość), funkcja adaptacji w określonym kontekście, intencja, która przyświecała procesowi wyrabiania adaptacji oraz zyskujące ostatnio na popularności, dzięki badaniom Kamilli Elliott, zastosowanie teorii wyjaśniających przystosowywanie się organizmów do warunków środowiska w badaniach humanistycznych nad adaptacją (Elliot 2012, 2013).

Linda Hutcheon zauważa, że „adaptacja to powtórzenie, ale powtórzenie bez replikacji" (Hutcheon 2006: 7). Stwierdzenie to jest o tyle ważne, że podkreśla ów brak bezpośredniego kopiowania, czy, jak to obecnie nazywamy potocznie, „kopiuj i wklej”. Właśnie ten aspekt adaptacji jest uważany przez autorkę za szczególnie ważny

8 Słownik języka polskiego, http://sjpd.pwn.pl/haslo/transformacja/, dostęp: 23.10.2014.

9 Słownik języka polskiego, http://sjp.pwn.pl/szukaj/adaptacja.html, dostęp: 27.10.2014. 
w przypadku form naśladowczych porcelan typu kraak wyrabianych w safawidzkiej Persji.

Należy zwrócić uwagę, że adaptacja jest jednym z nielicznych procesów, który zachodzi w wyniku pracy zbiorowej. Zupełnie jak w innych rodzajach adaptacji (np. filmowej czy literackiej), i tu rodzi się pytanie, kogo należy nazywać adaptatorem? Osobę, która pisze scenariusz na podstawie powieści, reżysera, aktorów wcielających się w role, a więc użyczających siebie samych w celu odwzorowania bohaterów książki, dekoratorów wnętrz i stylistów, a może producentów i sponsorów (bez ich hojnego finansowego wsparcia film przecież nigdy by nie powstał)?. To samo odnosi się do adaptacji w sztuce. Kto był adaptatorem w procesie wyrabiania naczyń przypominających chińską porcelanę błękitno-białą w XVII-wiecznej Persji? Ten, kto wybrał wzory i zaprojektował dekorację naczyń, czy może ten, kto uformował naczynie z gliny, a może ten, który naniósł rysunek na naczynie? $\mathrm{Ci}$, którzy byli odpowiedzialni za naniesienie szkliwa bądź ci, którzy wypalali je w piecu? A osoba, która złożyła zamówienie na wykonanie naczyń? Czy to nie za jej sprawą potoczył się cały bieg wydarzeń? Odpowiedź na te pytania nie jest jednoznaczna. Wszyscy wspomniani ludzie po części byli odpowiedzialni za proces adaptacji, wszyscy brali w nim udział.

Robert Stam zauważa:

Teoria adaptacji do tej pory ma już w swoim obrębie dobrze zarchiwizowane tropy i koncepcje, które opisują mutacje form między mediami: adaptacja, jako czytanie [reading], przepisywanie [rewriting], krytyka, translacja, transmutacja, metamorfoza, odtworzenie [recreation], transwokalizacja, resuscytacja, transfiguracja, aktualizacja, transmodalizacja, zaznaczenie, performance, dialogizacja, kanibalizm, rewizualizacja [reinvisioning], wcielenie, czy ponowne zaznaczenie [reaccentuation]. (Słowa z prefiksem „trans-” wskazują zmiany dokonane $\mathrm{w}$ adaptacji, podczas gdy te zaczynające się z prefiksem „re-” wskazują na rekombinacyjną funkcję adaptacji.) Każdy z tych terminów, jakkolwiek problematyczny, jako ostateczne wyjaśnienie adaptacji, naświetla inną stronę adaptacji (Stam 2005: 25).

Właśnie owa różnorodność aspektów adaptacji jest jedną z przyczyn, dla których autorka wybrała to słowo na określenie naśladowczej ceramiki wyrabianej w safawidzkiej Persji.

Zjawisko adaptacji jest bardzo powszechne i wcale nie takie młode, jak mogłoby się wydawać. Można je zaobserwować w każdej dziedzinie od antycznych sztuk, poprzez wiktoriańskie obrazy i wier- 
sze, do współczesnej kinematografii. Bliskość i wszechobecność sprawiają, że nie zwraca się uwagi w dzisiejszym świecie na jej istotę. Wszyscy chętnie wypowiadają się na temat najnowszych adaptacji filmowych znanych powieści, często mając pretensje do reżysera o pogwałcenie świętości dzieła literackiego tak bardzo przez nich uwielbianego. Stąd wynika brak szacunku dla adaptacji i jej twórców oraz dywagacje nad kwestią wierności oryginałowi. Stam spostrzega:

Język krytyki zajmującej się adaptacją filmową powieści bywa często głęboko moralistycznie zanurzony $\mathrm{w}$ takie sformułowania jak niewierność, zdrada, deformacja, pogwałcenie, wulgaryzacja i profanacja, każde niosące specyficzne sobie naładowanie skandalicznego sceptycyzmu. Niewierność trąci nutką wiktoriańskiej pruderii; zdrada wywołuje etyczną perfidię; deformacja nasuwa estetyczny niesmak; pogwałcenie przywołuje przemoc seksualną; wulgaryzacja wywołuje upadek klasowy; a profanacja oznajmia rodzaj religijnego świętokradztwa wobec „świętego słowa” (Stam 2000: 54).

Wszystkie te określenia, jakże często używane podczas podnoszenia słów krytyki w kierunku adaptacji, są głęboko krzywdzące. Co więcej, tak samo nieuzasadnione jak „sakralizacja” oryginału. Przecież oryginały nie powstawały w próżni, były inspirowane innymi, wcześniejszymi formami bądź wręcz - nie ujmując im świetności - adaptacjami i przeróbkami. Wypowiadający podobne sądy oczekują wierności, zapominając o tym, że w wielu, jeśli nie we wszystkich przypadkach adaptacji, jest ona po prostu niemożliwa. Sytuacja znacznie się komplikuje, gdy mamy do czynienia z przeniesieniem wzoru do innego kręgu kulturowego. Przepaść między spuścizną kulturową, a co za tym idzie, szeroko rozumianą tradycją i sztuką obydwu obszarów bywa tak głęboka, że dyskutowanie kwestii wierności wydaje się być co najmniej niestosowne. Ważniejsze jest zastanowienie się, jaki wpływ na siebie wywarły obydwie kultury i jakimi ciekawymi nowymi formami artystycznymi zaowocowało owo spotkanie.

W ocenie nieudanych adaptacji trudno nie zgodzić się z Hutcheon:

Podobnie, jak klasyczna imitacja, adaptacja również nie jest dosłownym kopiowaniem; to proces sprawiania, że adaptowany materiał staje się własny. [...] być może jedną z możliwości postrzegania nieudanych adaptacji jest nie w kategoriach niewierności, lecz w kategoriach braku kreatywności i umiejętności, by przerobić tekst na własny i, co za tym idzie, autonomiczny (Hutcheon 2006: 20). 
Kwestia sprawiania, że adaptowane wzornictwo staje się własnym, jest szczególnie ważna w przypadku safawidzkich adaptacji porcelan błękitno-białych. Nie znajdziemy wśród nich dokładnych kopii chińskich wyrobów. Mimo pozornego, widocznego na pierwszy rzut oka, bardzo bliskiego podobieństwa perskie naczynia ujawniają to, o czym pisze Hutcheon, czyli traktowanie chińskiego wzornictwa z taką samą swobodą, jak własne.

Kolejną ważną kwestią związaną $\mathrm{z}$ pojęciem adaptacji jest intertekstualność (interobrazowość). Bowiem:

[...] żaden tekst nie może być postrzegany w izolacji, ponieważ każdy tekst powtarza, nawiązuje i jest ostatecznie tworzony przez inne poprzednie teksty. Nie jest to kwestią źródeł, które inspirowały autora, ale wynika z ogólnej cytacyjnej natury języka. By w ogóle 'znaczyć', tekst nie może się powstrzymać od odbijania innych znaczeń, nie może powstrzymać się od przywoływania wcześniejszych kontekstów językowych i systemów znaczeń (Hartland 1999: 24).

Taka sama cytacyjna natura jest cechą sztuki, zatem nie powinna być ona postrzegana $\mathrm{w}$ izolacji. Palimpsestowy charakter adaptacji sprawia, że odbiór źródeł, których integralne części są w niej obecne, jest aktywny. Widz rozpoznaje znane mu fragmenty oryginału ${ }^{10} \mathrm{i} w$ ten sposób, ulegając czarowi tego, co znane i lubiane, zapoznaje się z odmiennością. George Kubler zwraca uwagę:

Ludzkie żądze w każdej chwili są rozdarte między repliką a wynalazkiem, między chęcią powrotu do znanego wzoru i chęcią ucieczki od niego przez nową odmianę. Ogólnie chęć powtarzania przeszłości przetrwała impulsy ucieczki od niej. Żaden czyn nie jest wystarczająco nowy i żaden nie może być właściwie osiągnięty bez wariacji. W każdym akcie wierność modelowi i ucieczka od niego są nierozerwalnie zmieszane $\mathrm{w}$ proporcjach, które zapewniają zauważalne powtórzenie $\mathrm{z}$ takimi drobnymi odmiennościami, na jakie pozwalają moment i okoliczności (Kubler 1970: 22).

${ }^{10}$ Linda Hutcheon dzieli publiczność na znającą i nieznającą oryginałów. Oczywiście jest między tymi dwoma grupami różnica, ponieważ każda $\mathrm{z}$ nich inaczej odbiera adaptację. Znający oryginały odbierają adaptacje jako adaptacje, a dla grupy niezaznajomionej z nimi jest to odbiór taki sam jak w przypadku innych dzieł niebędących adaptacjami. Por.: Hutcheon (2006: 126-127). 
Adaptacje są zatem zarówno powtórzeniami, jak i wariacjami. Wzornictwo ma możliwość podróżowania i nie znając granic ani wiz, osiedla się w innych kulturach, adaptując się do nowych warunków, podlegając mutacjom. Nowe formy pośrednie mają prawo być postrzegane na równi z innymi osiągnięciami artystycznymi, ponieważ „W wytworach ludzkiej wyobraźni adaptacja jest normą, a nie wyjątkiem" (Hutcheon 2006: 177).

\section{Nazwy grup adaptacji oraz ich definicje}

Z uwagi na fakt, że adaptacja jest postrzegana i badana głównie w kontekście tekstu i tekstualności, proponowane przez autorkę nazwy grup również powiązane są z tymi jej cechami. Cztery grupy, na które podzielono motywy dekoracyjne, nazwano odpowiednio: adaptacja dosłowna (literal adaptation ${ }^{11}$ ), adaptacja edytowana (edited adaptation), adaptacja zmieniona (altered adaptation) i adaptacja wolna (free adaptation). Definicje terminów przedstawiają się następująco:

Adaptacja dosłowna - motyw w największym stopniu przypomina oryginał $^{12}$, bardzo często jest to jego lustrzane odbicie. Małe różnice między oryginałem a adaptacją, polegające na innej liczbie płatków, liści czy innych drobnych elementów, wynikają raczej z indywidualnego stylu garncarza aniżeli $\mathrm{z}$ potrzeby dokonania zmian $\mathrm{w}$ rysunku wzoru.

Adaptacja edytowana - $\mathrm{w}$ tej grupie pojawiają się zmiany $\mathrm{w}$ motywach dekoracyjnych. Są trzy procesy, które zachodzą w tego rodzaju adaptacji. Pierwszy polega na usunięciu ważnego elementu motywu i nazywa się to adaptacją skróconą. Kolejny proces to usunięcie elementu i zastąpienie go innym - adaptacja zastępcza. Adaptacja rozszerzona natomiast polega na tym, że do motywu dodaje się element, który nie jest częścią oryginału. W przypadku perskich adaptacji często jest to element rodzimy, niebędący częścią tradycji chińskiej. Te trzy procesy nie są rezultatem indywidualnego stylu garnca-

${ }^{11}$ Praca doktorska autorki jest przygotowywana w języku angielskim, stąd przywołanie nazw grup w tym języku.

${ }^{12}$ Dla uproszczenia autorka przyjmuje, że oryginałami są chińskie porcelany typu kraak (głównie talerze). Należy tu podkreślić, że zjawisko adaptacji jest bardzo skomplikowane i adaptatorzy z dużą swobodą korzystali z innego dostępnego im wzornictwa, w tym również z innych epok i odmiennych rodzajów ceramiki. Same oryginały również są $\mathrm{w}$ pewnym stopniu naśladowcze i stanowią rodzaj adaptacji tego, co stworzono wcześniej. 
rza, ale wynikają z przemyślanej i szczegółowo zaplanowanej strategii dokonania zmian w danym motywie dekoracyjnym.

Adaptacja zmieniona - jest to najbardziej skomplikowana i trudna do wyjaśnienia grupa. Tutaj motywy podlegają jeszcze większym zmianom, które są wynikiem głębszego filtrowania ich w umyśle adaptatora. Ważne jest, że widz nadal może stwierdzić, że jest to forma naśladowcza, gdyż główne cechy charakterystyczne motywu pozostają nienaruszone. Kompozycja, ważne elementy, takie jak kwiaty czy skały, są zachowane.

Adaptacja wolna - w tej grupie występują motywy, które są najmniej podobne do oryginałów. Zmiany są duże i rozmyślne, mogą zawierać modyfikacje w stylu, kompozycji, perspektywie itp. Elementy rodzime są wprowadzone $\mathrm{z}$ dużą swobodą i umieszczane obok chińskich, często też stają się integralną częścią kompozycji, a sposób ich przedstawienia dopasowany jest do ogólnego stylu oryginału.

\section{Przykłady adaptacji}

Wyżej podane definicje trzech grup, na które zostały podzielone adaptacje, łatwiej będzie zrozumieć poprzez analizę wybranych przykładów.

Rys. 2 i 3 przedstawiają przykłady adaptacji dosłownej. W grupie tej zwraca uwagę duże podobieństwo adaptacji do oryginału. Nie jest to podobieństwo idealne, ale bardzo bliskie. Jak wspomniano, małe różnice między oryginałem a adaptacją, polegające na odmiennej liczbie drobnych elementów, wynikają raczej z indywidualnego stylu garncarza niż $\mathrm{z}$ potrzeby dokonania zmian $\mathrm{w}$ samym wzorze. $\mathrm{Na}$ rys. 2 znajdują się fragmenty perskiego (a) i chińskiego (b) talerza. Perski garncarz starał się dorównać oryginałowi poprzez oddanie takich szczegółów jak białe tło, pasek obramowania, liczba owoców czy umieszczenie liści wzdłuż łodygi i wokół owoców, a jednocześnie zmienił rysunek poprzez ujęcie go w lustrzanym odbiciu, dodanie czarnych kropek cieniujących i odmienne, mniej ostre zakończenia liści. Nieliczne zmiany, mimo że sprawiają wrażenie wprowadzonych celowo, mogą być wynikiem takich czynników jak odmienny sposób trzymania i operowania pędzlem oraz innych stanowiących o stylu malarskim określonego człowieka. Zastanawiające jest odwrócenie rysunku i przedstawienie go w odbiciu lustrzanym. Może ono wskazywać na przemożną chęć dokonania zmian, przy jednoczesnym zachowaniu podobieństwa, a lustrzane odbicie pozwala na taki zabieg.

Kolejna ilustracja (rys. 3) przedstawia węższe rezerwy talerzy. W tym przypadku zwraca uwagę bardzo bliskie podobieństwo per- 
skiej adaptacji do chińskiego oryginału i zachowanie układu kolorów. Z uwagi na to, że perski talerz ma wyższy otok (rys. 3a), cały rysunek musiał zostać zwężony i wydłużony, stąd wyższy wzór. Zmienił się też największy koralik - również został ujęty w odbiciu lustrzanym.

Przykład adaptacji edytowanej rozszerzonej przedstawia rys. 4a. Sznur korali na wąskiej rezerwie jest wyraźnie dłuższy od typowego przedstawienia go przez Chińczyków (rys. 4b). Lekkie cieniowanie łuku u góry motywu niestety uległo rozmyciu $\mathrm{w}$ procesie wypalania naczynia i połączyło się ze szkliwem, tworząc charakterystyczne zacieki. Zachowało się za to dość dobrze po przeciwległej stronie - u dołu.

Adaptacja edytowana jest jedną z najbardziej dynamicznych grup. Procesy edytorskie często zachodziły symultanicznie - doskonałym przykładem tego typu zabiegów jest lustro talerza ze zbiorów Muzeum Wiktorii i Alberta w Londynie (rys. 5a). Stosunkowo duże lustro talerza - przy ogólnej średnicy talerza wynoszącej prawie $50 \mathrm{~cm}$ musi ono mierzyć około $30 \mathrm{~cm}$ - mogło dać pole do popisu i zagęszczenia dekoracji. Perski twórca postąpił jednak przeciwnie, zdecydował się dodać więcej światła między łodygi kwiatów (adaptacja edytowana skrócona). Zachował przy tym główne cechy charakterystyczne dla motywu dekoracyjnego przedstawiającego bukiet kwiatów $\mathrm{w}$ wazonie na podstawce $\mathrm{z}$ korzeni, a więc wazon i jego kształt, kwiaty z licznymi liśćmi, zwoje, podstawkę z korzeni oraz balustradę bądź płot. Jednocześnie zdecydował się dodać element rodzimy, niespotykany na chińskich oryginałach - kontrastujące z rysunkiem wazonu dwie bestie gryzące się nawzajem. Innymi elementami dodanymi, a więc zaliczającymi się do procesu adaptacji edytowanej rozszerzonej, są kępki wąskich liści trawy wystające zza balustrady oraz znany $\mathrm{z}$ innych błękitno-białych porcelan, w tym kraaków, owad w locie. Oprócz białych zwierząt zwraca uwagę odmienne potraktowanie zarysu korzeni. Wytłumaczyć to można nieznajomością podstawek tego typu w Persji. Twórcy zapewne uznali je za rozłożyste nóżki i potraktowali dość skrótowo. Przeniesienie głowy berła ruyi z wazonu, gdzie zazwyczaj był umieszczany przez Chińczyków, na spód i przymocowywanie go do podstawki zdaje się dowodzić poprawności tego wniosku. Przykładem adaptacji zastępczej jest usunięcie opadłych liści bądź płatków i zastąpienie ich motywem znanym z innych naczyń - stylizowanym trygramem.

Adaptacja zmieniona to kolejny rodzaj adaptacji wyszczególniony przez autorkę. Jak sugeruje nazwa, zmienione i przefiltrowane motywy zachowują ogólne cechy swoich źródeł. Dobrym przykładem jest tutaj fragment talerza przedstawiony na rys. 6a. Perski artysta oddał ogólne cechy scenki - znajduje się tam owad w locie, stylizo- 
wane chmury, kwiaty i szerokie liście. Jednak rysunek wyraźnie odbiega od chińskiej metody przedstawiania tego typu scenek, jest cięższy, a pewne elementy, jak kwiaty i ich liście, zostały potraktowane dość skrótowo poprzez pojedyncze ruchy pędzla.

Innym dobrym przykładem ilustrującym adaptację zmienioną jest lustro talerza ze zbiorów Muzeum Wiktorii i Alberta w Londynie (rys. 7). Cała kompozycja zachowała ogólne cechy pierwowzoru (por. z rys. 5b), to znaczy, że obecna jest balustrada, podstawka z wazonem i kwiaty, jednak zostały one zmienione. Balustrada jest tylko zarysowana serią łuków, a sam wazon i podstawka zostały ujęte w znacznym uproszczeniu. Większą dbałość o szczegóły wykazano w przypadku kwiatów, gdzie zaznaczono żyłki liści i cieniowanie płatków. Finezyjności całej kompozycji dodają wystające po obu stronach bukietu gałązki.

Ostatnia grupa zawiera adaptacje wolne, czyli takie, które są najmniej podobne do źródeł. Zmiany dokonane w motywach dekoracyjnych są duże i przemyślane. Lustro talerza $\mathrm{z}$ rys. 8a przedstawia taki rodzaj adaptacji. Scenka z dwoma jeleniami idącymi zboczem góry tylko przypomina chińską. Różnice są na tyle duże, że trudno zakwalifikować motyw do innego rodzaju adaptacji, a jednocześnie na tyle przemyślane, że widz z łatwością rozpozna chińskie źródło inspiracji.

Podobnie przedstawia się sytuacja przy kolejnym przykładzie (rys. 9). Dekoracja tylko przypominająca chińską - wazon o charakterystycznym kształcie, kwiaty w nim i zwój. Kwiaty umieszczone w miejscu podstawki przywodzą na myśl te używane przy dekoracji dywanów i innych tekstyliów bądź ceramiki tureckiej Iznik. Ten przykład pokazuje, co było ważne dla perskiego garncarza, które elementy omijał, a które zostawiał. Wyraźnie daje się zauważyć pewien rodzaj konsekwencji w działaniu, której obserwacja jest również jednym z celów badań autorki.

Należy wspomnieć, że adaptacje porcelany typu kraak wykonywano również $\mathrm{w}$ innych częściach Persji i w mniej popularnych ośrodkach. Rys. 10a i 10b przedstawiają przykłady tak zwanych wyrobów Kubachi charakteryzujących się użyciem kolorowych angob do zdobienia naczyń. Jak można zaobserwować na obydwu talerzach, idea podziału na rezerwy została zachowana. Na lustrze naczynia przedstawionego na rys. 10a namalowano sarnę pośród kwiatów, których kształt, jak i charakterystyczne pasy z elementami ślimakowatymi, zapożyczone zostały z ceramiki tureckiej Iznik. Z kolei lustro talerza ujętego na rys. $10 \mathrm{~b}$ stanowi typowe dla Kubachi przedstawienie elementów roślinnych $\mathrm{z}$ charakterystycznie wygiętymi łodygami. Tu również zachowano ideę podziału na rezerwy, które dodatkowo za- 
znaczono grubą warstwą błękitu kobaltowego. Tak duża swoboda w traktowaniu chińskich źródeł nie wyklucza możliwości, że w rzeczywistości adaptowano perskie adaptacje chińskich oryginałów.

Porcelanowe naczynia typu kraak tak bardzo podobały się Persom, że wyrabiano je również u schyłku panowania Safawidów. Przykład takiego późnego wyrobu, datowanego na lata 1690-1720, przedstawia rys. 10c. Dekoracja, mimo że bardziej oszczędna niż na poprzednich talerzach, bardziej przypomina chińskie oryginały. Na lustrze umieszczono charakterystyczny układ abstrakcyjnych elementów roślinnych, które, podobnie jak beżowy odcień angoby, były również umieszczane na innych perskich naczyniach błękitno-białych wyrabianych na przełomie XVI i XVII wieku.

Zjawisko adaptacji, mimo znacznego skomplikowania i stosunkowo małego zainteresowania wśród uczonych zajmujących się historią sztuki, zasługuje na uwagę. Pewne pojęcia, którymi określano dotąd naśladowcze formy artystyczne, zużyły się lub niedostatecznie odpowiadają procesom, które zachodzą podczas powielania materiału źródłowego. Czynności te nie są li tylko mechanicznym kopiowaniem i wklejaniem obrazków. Są czymś więcej, albowiem podczas tego rodzaju aktu twórczego wzory ulegają przeobrażeniom, które są wynikiem głębokiej analizy dokonywanej w umyśle twórcy. Na ile są one rezultatem zamierzonego i planowanego działania, a na ile dokonują się pod wpływem otoczenia bądź wewnętrznego zasobu wzornictwa autora, pozostaje kwestią otwartą. Pewne jest, że chińskie porcelany błękitno-białe wywarły ogromny wpływ na perską ceramikę. Niezwiązani konwencją tak sztywno jak Chińczycy, safawidzcy twórcy czerpali z niemal nieograniczonego bogactwa form i kształtów chińskiej porcelany. Niebywała dbałość o szczegóły zdradza, że byli wystarczająco utalentowani, by być w stanie wykonywać perfekcyjne kopie chińskich oryginałów. Jednak nie zdecydowali się na taki zabieg, woleli odchodzić w mniejszym lub większym stopniu od źródła i wzbogacać je poprzez dodawanie rodzimych elementów dekoracyjnych. Właśnie taka postawa stanowi o wyjątkowości adaptacji chińskich porcelan wykonywanych w safawidzkiej Persji.

\section{Bibliografia}

Allen, Robert. 1992. The Penguin English Dictionary. London: Penguin Group.

Eliott, Kamilla. 2003. Rethinking the Novel/Film Debate. Cambridge: Cambridge University Press. 
Eliott, Kamilla. 2012. The Adaptation of Adaptation: A Dialogue between the Sciences and Humanities: Pascal Nicklas, Oliver Lindner (red.). Adaptation and Cultural Appropriation: Literature, Film, and the Arts. Berlin: Walter De Gruyter, 145-161.

Golombek, Lisa, Robert B. Mason, Patricia Proctor. 2001. Safavid Potters' Marks and the Question of Provenance, Iran 39, 207-239.

Golombek, Lisa, Robert B. Mason, Patricia Proctor, Eileen Reilly. 2014. Persian Pottery in the First Global Age. The Sixteenth and Seventeenth Centuries. Leiden: Brill.

Hartland, Richard. 1999. Literary Theory from Plato to Barthes. An Introductory History. Hong Kong: MacMillian Press.

Hutcheon, Linda. 2006. A Theory of Adaptation. New York: Routledge.

Jacoby, Marcin. 2009. Powtórzenie i falsyfikat w malarstwie chińskim. Warszawa: Trio.

Kubler, George. 1970. The Shape of Time: Remarks on the History of Things. New Haven: Yale University Press.

Rinaldi, Maura. 1989. Kraak Porcelain: A Moment in the History of Trade. London: Bamboo Publishing.

Stam, Robert. 2000. Beyond Fidelity: the Dialogics of Adaptation: James Naremore (red.). Film Adaptation. New Brunswick: Rutgers University Press, 54-76.

Stam, Robert. 2005. Introduction: The Theory and Practice of Adaptation: Robert Stam, Alessandra Raengo (red.). Literature and Film: A Guide to the Theory and Practice of Film Adaptation. Chichester: Blackwell Publishing, 1-52.

Volker, T. 1971. Porcelain and the Dutch East India Company: As Recorded in the Dagh-Registers of Batavia Castle, Those of Hirado and Deshima and Other Contemporary Papers 1602-1682. Leiden: Brill.

\section{Źródła internetowe}

Doroszewski, Witold (red.). Słownik języka polskiego. Warszawa: PWN. Reprint online, http://sjpd.pwn.pl/haslo/transformacja/, dostęp: 23.10.2014.

Drabik, Lidia. Słownik języka polskiego. Warszawa: PWN. Reprint online, http://sjp.pwn.pl/szukaj/t\%C5\%82umaczenie.html, dostęp: 23.10.2014.

Drabik, Lidia. Słownik języka polskiego. Warszawa: PWN. Reprint online, http://sjp.pwn.pl/szukaj/adaptacja.html, dostęp: 27.10. 2014. 
The Metropolitan Museum of Art. The Collection Online, http://www.metmuseum.org/collection/the-collectiononline $/$ search $/ 449547 ?=$ \&imgNo $=0 \&$ tabName $=$ gallery-label, dostęp: 4.07.2014.

The Metropolitan Museum of Art. The Collection Online, http://www.metmuseum.org/collection/the-collectiononline $/$ search $/ 451907 ?=$ \&imgNo $=0 \&$ tabName $=$ gallery-label, dostęp: 4.07.2014. 


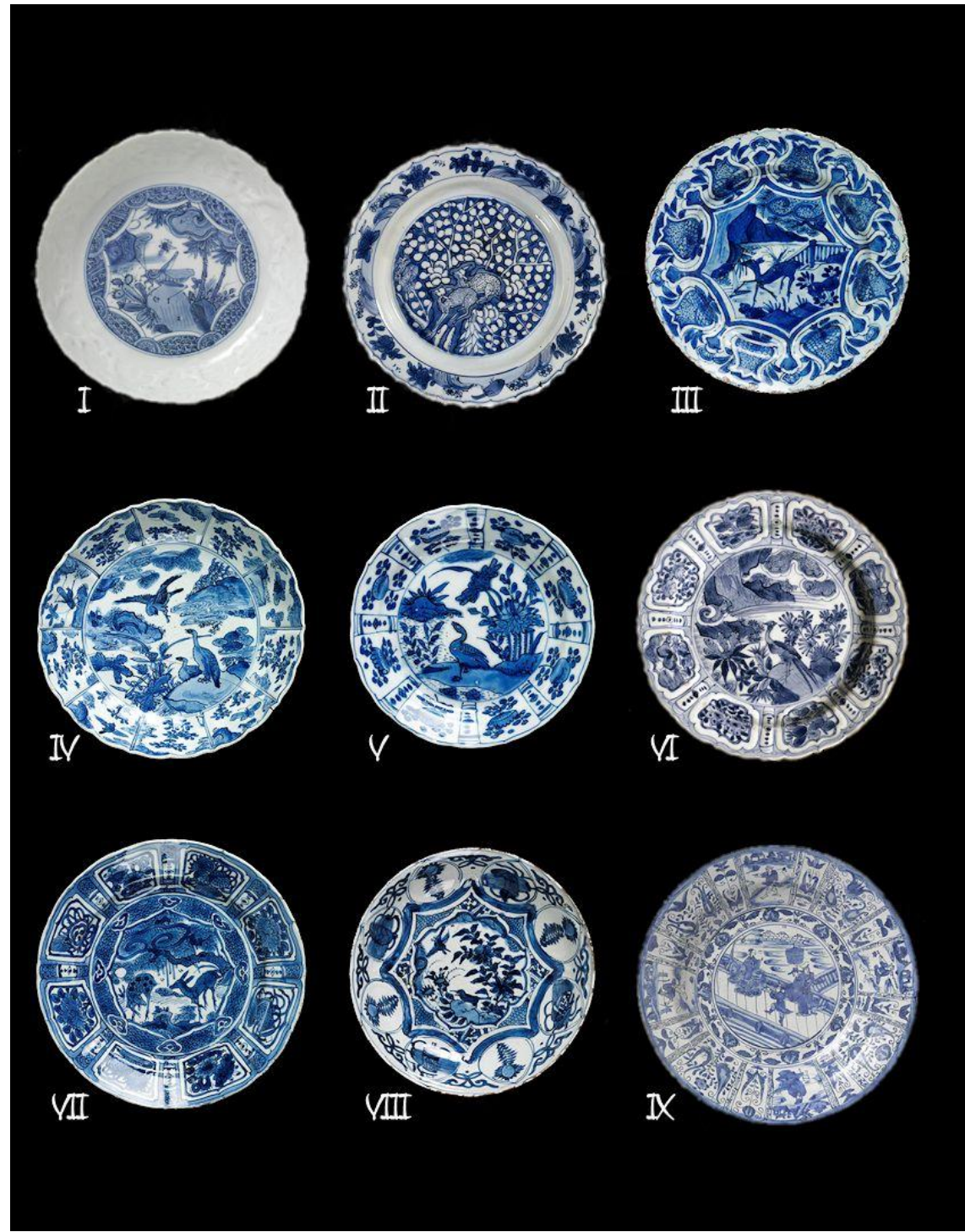

Rys. 1. Podział talerzy na 9 grup. Grupy I-III widoczny brak podziału na rezerwy; IV-VI pojawiają się rezerwy; VII-IX proszę zwrócić uwagę na podobieństwo grupy VIII i III. Talerze; Jingdezhen, dynastia Ming (1368-1644); porcelana malowana podszkliwnie kobaltem; grupy I, II, IX - numery inwentarzowe: AK-MAK-621, AK-BRK-1967-181, AK-RBK-15794, Rijksmuseum, Amsterdam; grupy III, IV, V, VII, VIII - numery inwentarzowe: C.4671918, C.461-1918, C.163-1923, 396-1903, CIRC.343-1919, (C) Victoria and Albert Museum, London; grupa VI - numer inwentarzowy: 1923,0611.1, (C) The Trustees of the British Museum. 

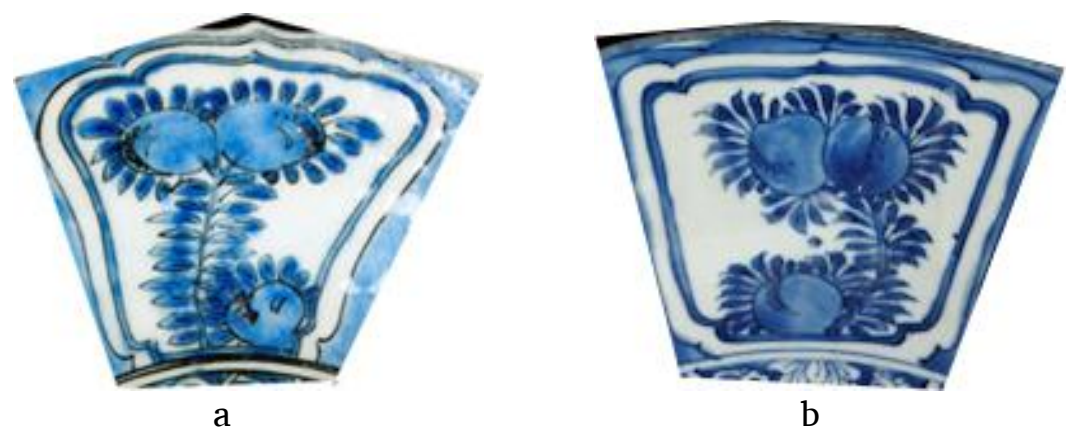

Rys. 2. Przykład adaptacji dosłownej. (a) fragment perskiego talerza; 15501642; frytowa masa ceramiczna; dekoracja podszkliwna malowana kobaltem i czernią; wymiary: wysokość: $5,2 \mathrm{~cm}$, średnica: $27,3 \mathrm{~cm}$, średnica stopki: 13,2 cm; numer inwentarzowy: 1111-1876; (C) Victoria and Albert Museum, London. (b) fragment chińskiego talerza; Jingdezhen; 1605-1615; porcelana malowana podszkliwnie kobaltem; wymiary: średnica: $50 \mathrm{~cm}$; numer inwentarzowy: C.1872-1921; (C) Victoria and Albert Museum, London.

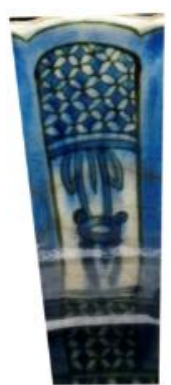

a

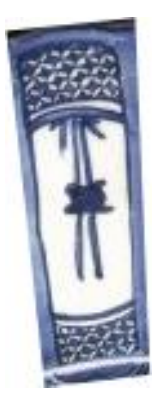

b

Rys. 3. Przykład adaptacji dosłownej. (a) fragment perskiego talerza; ok. 16001640; frytowa masa ceramiczna malowana dwoma odcieniami błękitu kobaltowego i czernią; wymiary: wysokość: $8,1 \mathrm{~cm}$, średnica: $47,1 \mathrm{~cm}$; numer inwentarzowy: 245-1884; (C) Victoria and Albert Museum, London. (b) fragment chińskiego talerza; ok. 1590-1610, Jingdezhen; porcelana malowana podszkliwnie kobaltem; wymiary: wysokość: $9,5 \mathrm{~cm}$, średnica: $50,3 \mathrm{~cm}$; numer inwentarzowy: Franks.191; (C) The Trustees of the British Museum 


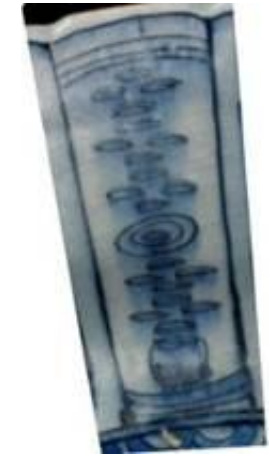

a

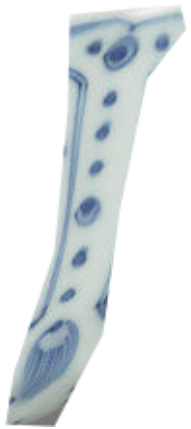

b

Rys. 4. Przykład adaptacji edytowanej rozszerzonej. (a) fragment perskiego talerza; XVI wiek; frytowa masa ceramiczna, podszkliwna malatura kobaltem i czernią; wymiary: wysokość: 7,5 cm, średnica: $46,3 \mathrm{~cm}$; numer inwentarzowy: 1136-1876; (c) Victoria and Albert Museum, London. (b) fragment chińskiej miseczki typu kraak; Jingdezhen; 1575-1600; porcelana malowana podszkliwnie kobaltem; wymiary: wysokość: $8,9 \mathrm{~cm}$, średnica: $14,2 \mathrm{~cm}$; numer inwentarzowy: 1620-1876; (C) Victoria and Albert Museum, London.

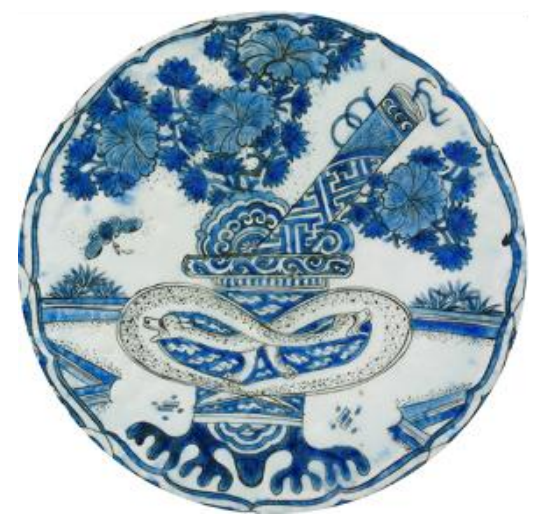

a

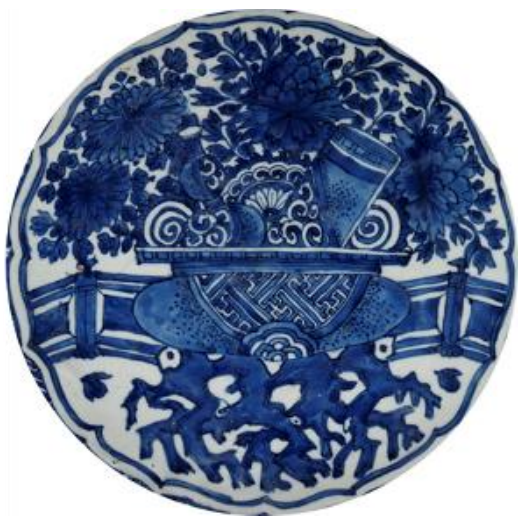

b

Rys. 5. Przykład adaptacji edytowanej. (a) fragment perskiego talerza; XVI wiek; frytowa masa ceramiczna malowana podszkliwnie 2 odcieniami błękitu i czernią; wymiary: wysokość: $8,8 \mathrm{~cm}$, średnica: $48,9 \mathrm{~cm}$; numer inwentarzowy: 2810-1876; (C) Victoria and Albert Museum, London. (b) fragment chińskiego talerza; Jingdezhen; 1605-1615; porcelana malowana podszkliwnie kobaltem; wymiary: średnica: $50 \mathrm{~cm}$; numer inwentarzowy: C.1872-1921; (C) Victoria and Albert Museum, London. 


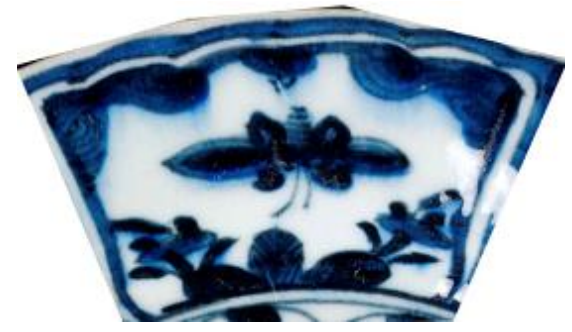

a

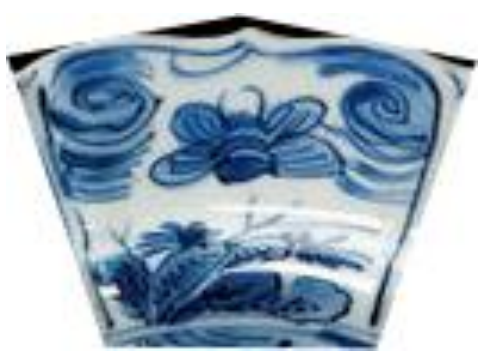

b

Rys. 6. Przykład adaptacji zmienionej. (a) fragment perskiego talerza; XVII wiek; frytowa masa ceramiczna malowana podszkliwnie kobaltem; wymiary: wysokość: 4,9 cm, średnica: $24 \mathrm{~cm}$; numer inwentarzowy: 2706-1876; (c) Victoria and Albert Museum, London. (b) fragment chińskiego talerza; Jingdezhen; 1573-1620; porcelana malowana podszkliwnie kobaltem; wymiary: średnica: $21 \mathrm{~cm}$; numer inwentarzowy: C.579-1910; (C) Victoria and Albert Museum, London.

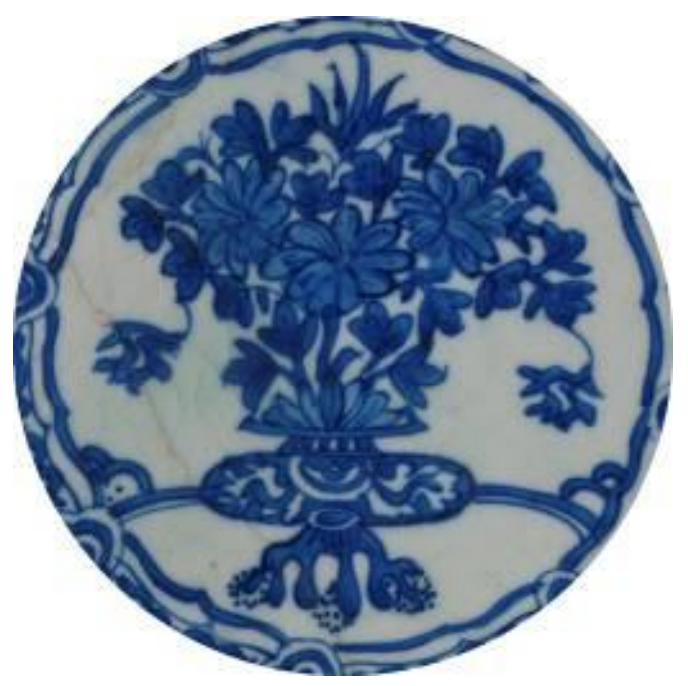

Rys. 7. Przykład adaptacji zmienionej. Fragment perskiego talerza; XVII wiek; frytowa masa ceramiczna malowana podszkliwnie kobaltem; wymiary: wysokość: 8,1 cm, średnica: 44,5 cm; numer inwentarzowy: 980-1886;

(C) Victoria and Albert Museum, London. 


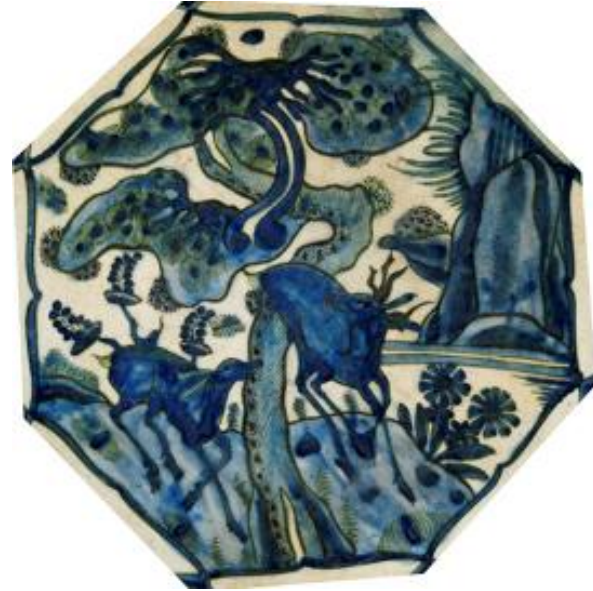

a

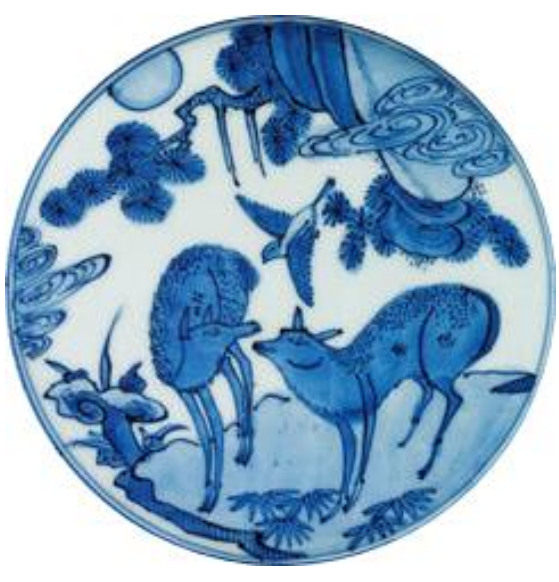

b

Rys. 8. Przykład adaptacji wolnej. (a) fragment perskiego talerza; XVII wiek; frytowa masa ceramiczna malowana podszkliwnie błękitem kobaltowym i czernią; wymiary: wysokość: $8,1 \mathrm{~cm}$, średnica: $47,1 \mathrm{~cm}$, średnica stopki: 23,5 cm; numer inwentarzowy: 245-1884; (C) Victoria and Albert Museum, London. (b) fragment chińskiego talerza; Jingdezhen; ok. 1573-1620; porcelana malowana podszkliwnie kobaltem; wymiary: średnica: $20 \mathrm{~cm}$; numer inwentarzowy: C.465-1918; (C) Victoria and Albert Museum, London.

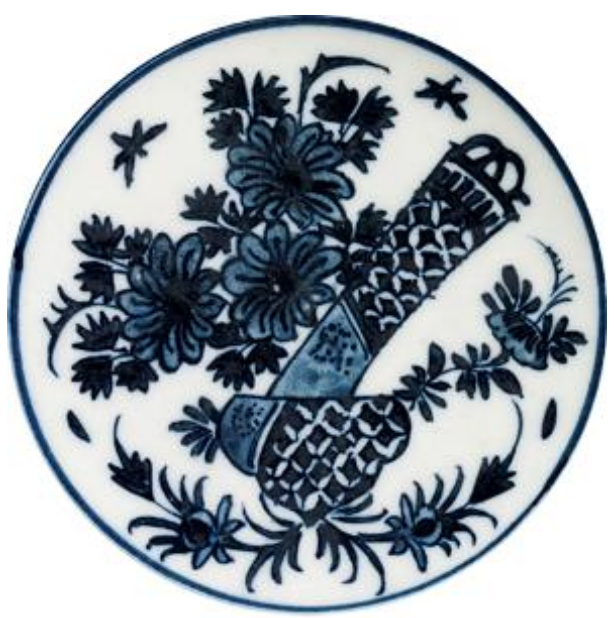

Rys. 9. Przykład adaptacji wolnej. Fragment perskiego talerza; XVII wiek; frytowa masa ceramiczna malowana podszkliwnie kobaltem; wymiary: wysokość: 5,1 cm, średnica: 22,4 cm; numer inwentarzowy: 2696-1876;

(C) Victoria and Albert Museum, London. 


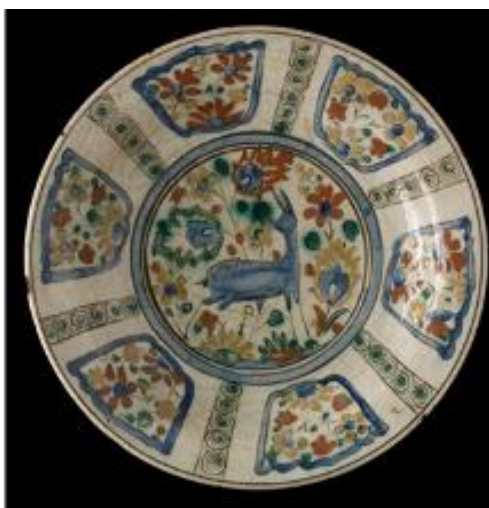

a

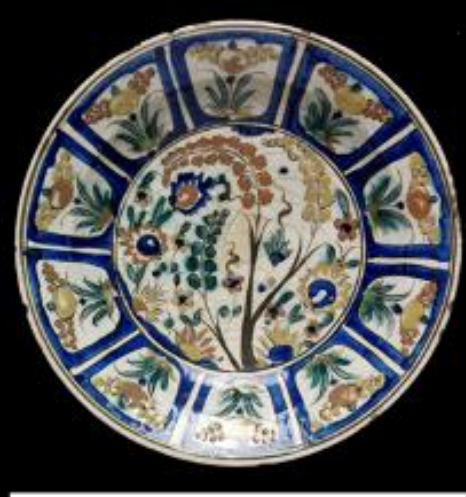

b

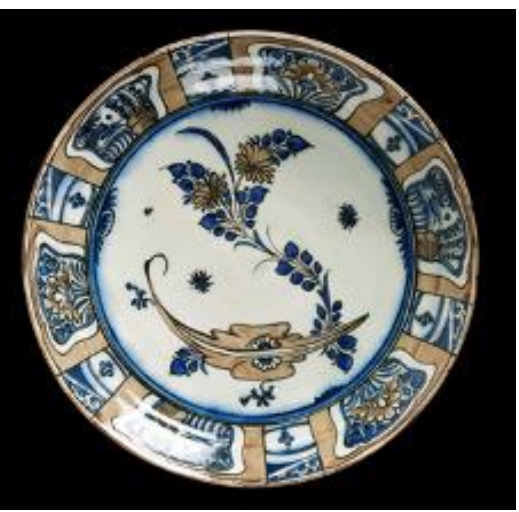

C

Rys. 10. Przykłady naczyń z malaturą podszkliwną kobaltem i kolorowymi angobami. (a) talerz; Iran; ok. 1600; frytowa masa ceramiczna z dekoracją podszkliwną malowaną kobaltem i kolorowymi angobami; wymiary: średnica: 34,3 cm; numer inwentarzowy: 818-1904; (C) Victoria and Albert Museum, London. (b) talerz; Isfahan, Iran; 1600-1650; frytowa masa ceramiczna zdobiona podszkliwnie angobami i kobaltem; średnica: 33,7 cm; numer inwentarzowy: 1456-1904; (c) Victoria and Albert Museum, London. (c) talerz; Iran; 1690-1720; frytowa masa ceramiczna malowana angobą i kobaltem; wymiary: średnica: 36,5 cm; numer inwentarzowy: C.1967-1910;

(C) Victoria and Albert Museum, London.

\section{Abstract}

\section{Safavid adaptations of Chinese kraak porcelain}

Decorative motives known from the Chinese blue-and-white porcelain began to appear massively on Persian ceramics between the $14^{\text {th }}$ and $17^{\text {th }}$ century. Interestingly, the initial role of adaptations being a substitute for an expensive original became something more a source of inspiration for making new vessels decorated not only in cobalt blue but also in colorful slips. The article is dedicated to an analysis of Persian adaptations of Chinese kraak porcelain made during the Safavid period (1501-1732). Due to the fact that the process of adaptation was very complex and there is no 1:1 copy of a kraak dish in Iran, author in her research has to focus on comparing individual motifs instead of the whole vessels. She introduces new categorization of the adapted designs and divides them into 4 groups depending on how close they resemble the Chinese origi- 
nals: in group 1 called literal adaptations the motifs are most similar to the originals; in group 2 named edited adaptations are those that have an element added or taken away; in group 3, altered adaptations, the designs undergo changes in style but still bear the basic characteristics of the originals; in group 4, free adaptations, are those that only resemble the Chinese ones.

Keywords: adaptation, imitation, kraak, porcelain, ceramics, Safavids, Persia 